\title{
The Role of Integrated Reporting in Emerging Market: Earnings Quality and Debt Maturity
}

\author{
Pria Aji Pamungkas ${ }^{1}$, Amrie Firmansyah ${ }^{2,}$ Resi Ariyasa Qadri' ${ }^{3,}$ Agung Dinarjito ${ }^{4,}$ Zef \\ Arfiansyah $^{5}$ \\ 1,2Program Diploma IV Akuntansi Sektor Publik, Politeknik Keuangan Negara STAN \\ 3,4,5 Program Diploma III Akuntansi, Politeknik Keuangan Negara STAN \\ Email Address: \\ priaajipamungkas@gmail.com,amrie@pknstan.ac.id,resi.ariyasa@gmail.com, \\ agungdije@gmail.com,zef.arfiansyah@pknstan.ac.id
}

\begin{abstract}
The maturity structure of debt can have financial and operational consequences for a firm as debt maturity is a key aspect of financial flexibility. Moreover, debt maturity can impact a firm's ability to undertake long-term productive investments and, as a result, affect economic activity. This study aims to examine the effect of earnings quality on debt maturity and the role of Integrated Reporting (IR) in moderating these effects. This study's methodology is a quantitative approach with multiple linear regression models and panel data. The sample employed in this study is manufacturing companies listed on the Indonesia Stock Exchange (IDX). The type of data employed in this study is secondary data sourced from financial statements and annual reports from 2016 to 2020 . The sample selection using a purposive sampling method with the number of samples amounted to 595 firm-year observations. The results of this study suggest that earnings quality does not affect debt maturity. Additional tests show that income maximization companies tend to have shorter debt maturity. However, IR failed to moderate the effect of earnings quality on debt maturity. This study indicates that the Financial Services Authority (OJK) needs to conduct better monitoring and regulation to increase creditor protection through optimal debt policy disclosure from the companies.
\end{abstract}

Keywords: debt maturity, earnings quality, earnings management, integrated reporting.

\begin{abstract}
Abstrak: Struktur maturitas utang dapat memiliki konsekuensi keuangan dan operasional bagi perusahaan karena jatuh tempo utang merupakan aspek kunci dari fleksibilitas keuangan. Penelitian ini bertujuan untuk menguji pengaruh kualitas laba terhadap maturitas utang dan peran Integrated Reporting (IR) dalam memoderasi efek tersebut. Metodologi penelitian ini adalah penelitian kuantitatif dengan analisis regresi data panel. Sampel yang digunakan dalam penelitian ini adalah perusahaan manufaktur yang terdaftar di Bursa Efek Indonesia (BEI). Jenis data yang digunakan dalam penelitian ini adalah data sekunder berupa laporan keuangan dan laporan tahunan dari tahun 2016 sampai dengan tahun 2020. Pemilihan sampel menggunakan metode purposive sampling sebesar 595 observasi. Hasil penelitian ini menunjukkan bahwa kualitas laba tidak berpengaruh terhadap maturitas utang. Pengujian tambahan yang dilakukan menunjukkan bahwa perusahaan yang melakukan income maximization cenderung dinilai lebih berisiko oleh kreditur. Selain itu, IR gagal memoderasi pengaruh kualitas laba terhadap jatuh tempo utang. Studi ini menunjukkan bahwa Otoritas Jasa Keuangan (OJK) perlu melakukan
\end{abstract}


pengawasan dan pengaturan yang lebih baik untuk meningkatkan perlindungan kreditur melalui pengungkapan kebijakan maturitas utang yang optimal dari perusahaan.

Kata Kunci: Maturitas Utang, Kualitas Laba, Manajemen Laba, Integrated Reporting.

\section{INTRODUCTION}

In a perfect capital market, the firm's decisions regarding its capital structure are irrelevant (Modigliani and Miller, 1958). However, the existence of market imperfections such as taxes (Modigliani and Miller, 1963), information asymmetry (Myers, 1984), and agency costs (Jensen and Meckling, 1976; Myers, 1977) encourage companies to make optimal financing decisions. From the company's perspective, debt maturity can reduce the costs associated with these market imperfections (Jordan, 2018). Wrong debt maturity choices can make the company face potential rollover risks and interest rate fluctuations and make it challenging to achieve optimal company growth (Orman and Köksal, 2017).

Maturity structure mismatch between short-term obligations to finance long-term investments (strong maturity mismatch) by many companies is seen as one of the main factors explaining 2007-2009 (Brunnermeier and Oehmke, 2013). Short-term debt is also identified as poor performance on the part of the debtor by the lender (Manuelli, 2019). Furthermore, (Almeida et al., 2011) concluded that after the 2007 Financial Crisis, the rate of return on bonds issued by companies increased drastically. This increase in return results in higher costs of corporate debt so that the company is increasingly having difficulty getting long-term financing.

Debt maturity is a critical instrument for reducing agency costs from debt financing activities (Adachi-Sato and Vithessonthi, 2019). Decisions related to optimal debt maturity can mitigate agency problems between the lender as the principal and the company manager as the agent. The preparation of debt contracts, one of the main components of debt maturity, can mitigate agency problems in the form of underinvestment problems, asset substitution or risk shifting problems, and overinvestment problems (CasinoMartínez et al., 2019). Lower debt maturity can reduce agency problems because lenders can conduct more routine supervision during the debt contract renegotiation process. Investors prefer to buy short-term debt rather than long-term debt because short-term debt reduces the company's default risk in the interim period (Adachi-Sato and Vithessonthi, 2019). However, from the perspective of company managers, longer debt maturities are more profitable. Companies do not need to renew debt contracts every year and are more protected from the risk of cash volatility (Jordan, 2018). These differences in interests can lead to a maturity mismatch and encourage the risk of bankruptcy (Farhi and Tirole, 2012).

The maturity mismatch's impact can increase the company's risk of default when the debt matures, especially for companies experiencing liquidity problems. The difference in interests between shareholders and debtholders related to the debt maturity structure is one of the policies that company managers must consider well (Manuelli, 2019). Debt maturity policies can affect the level of investment and company production (Jungherr and Schott, 2020). However, determining the proportion of the optimal debt maturity structure is still a difference of opinion among practitioners and academics (Della Seta et al., 2020). In 
addition, the market (especially debt investors) responded to the non-optimal structure of corporate debt maturity with a higher expected rate of return, thereby increasing the company's cost of debt. As a result, the company will find it more challenging to obtain additional funds through debt instruments to affect its growth. Therefore, the debt maturity structure is essential for further investigation.

Previous studies examine the factors that affect debt maturity include systematic risk (H. Chen et al., 2021), cost stickiness (Habib and Costa, 2021), financial statement's comparability (Do, 2020), green credit policy (Xu and Li, 2020), earnings management (Maurice et al., 2020; Habib and Costa, 2021; Rey et al., 2020), earnings quality (VanKhanh and Hung, 2020; De Meyere et al., 2018), corporate social responsibility (Nguyen et al., 2020), corporate investment (Jungherr and Schott, 2020; Adachi-Sato and Vithessonthi, 2019), policy uncertainty (Datta et al., 2019; Pan et al., 2019), accounting conservatism (Salehi and Sehat, 2019), asset quality (Olibe et al., 2019; Gong and Wei, 2019), and fair value accounting (Ghanbari et al., 2018; Wang and Zhang, 2017). (CasinoMartínez et al. 2019), (Manuelli, 2019), and (Kashefi Pour and Lasfer, 2019) investigate the effect of country characteristics and macroeconomic factors on debt maturity.

(De Meyere et al., 2018) examine the effect of earnings quality on the debt maturity structure. Profits of companies that can better predict future cash flows can reduce information asymmetry between creditors and debtors to increase the company's ability to access long-term debt. This finding is in line with (Maurice et al., 2020) and (Rey et al., 2020), which shows that companies that carry out aggressive earnings management activities tend to have lower long-term debt structures. However, the results of studies on the effect of earnings quality on debt maturity are still contradictory. (VanKhanh and Hung, 2020) used data from companies listed on the Vietnam Stock Exchange in 20102018. The results show that earnings quality has a negative effect on debt maturity. The difference in the results of previous studies may occur due to differences in the characteristics of companies in developed and developing countries that are the object of research. Research related to the effect of earnings quality on debt maturity has not been carried out in Indonesia. Therefore, further investigation is needed to prove the differences in the results of previous studies, especially in the context of developing countries.

This research also includes Integrated Reporting (IR) as a moderator that has never been used before to test earnings quality's effect on debt maturity. The increasing attention related to sustainable issues by companies worldwide has led to sustainable reporting (SR) development over the last two decades (Kolk and Perego, 2010; Mårtensson and Westerberg, 2016). Integrated reporting is considered the better 'tool' to make a breakthrough in SR issues (Lai et al., 2016). Previous research has shown that SR does not always reflect the company's actual involvement in sustainability (Alonso-Almeida et al., 2013). Proponents of IR believe that IR will bring greater transparency to a company's commitment to sustainability by showing the relationship between financial performance and sustainability in a single document (Eccles and Krzus, 2010; Adams, 2013; King and Roberts, 2013).

Before the IIRC introduced the IR concept in 2013, companies issued separate voluntary reports (e.g., sustainability reports or intellectual capital statements) in addition to mandatory financial reports to inform stakeholders regarding the company's value creation process (Wang et al., 2020). Those separate reports often cause stakeholders to comprehend an information-overload effect (de Villiers et al., 2014). IR is the latest 
attempt to remove corporate reporting silos by providing only one report linking a company's material financial and non-financial information (Grassmann, 2021; Cortesi and Vena, 2019; Di Vaio et al., 2020). Therefore, IR aims to provide investors with a holistic picture of how non-financial capital relates to creating a firm's financial value (Landau et al., 2020; Tlili et al., 2019).

The implementation of IR is part of the company's legitimacy strategy (Haji and Anifowose, 2016). Companies take symbolic or substantive actions, or a combination of the two, to show the company's existence, one of which is through the presentation of voluntary IR (Vourvachis et al., 2016). The Indonesian government has not yet issued a specific regulation that requires the presentation of IRs by public companies in Indonesia. Therefore, the presentation of IR in Indonesia is still voluntary. Companies in Indonesia that present IR want to show the existence of their institutions in the eyes of the community and other stakeholders (Dosinta et al., 2017). (Muttakin et al., 2020) examine the role of IR in moderating the effect of financial reporting quality on the cost of U.S. corporate debt. In companies that present IR, financial reporting's quality can significantly reduce the company's debt cost. Higher quality financial reporting complemented by IR presentation can reduce information processing costs by lenders in assessing company prospects. In addition, (Grassmann, 2021) shows that the presentation of IR can strengthen the effect of CSR spending on firm value.

This research contributes both theoretically and practically. Theoretically, this study adds to empirical evidence regarding the factors that can influence debt maturity policies and the impact of IR reporting on debt maturity in Indonesia. Practically, this research can be used by the company's decision-makers regarding the optimal debt maturity policy. For investors and creditors, this research can be used as a consideration when entering into debt contracts.

The paper is structured as follows: Section 2 - Literature Review and Hypotheses Development, Section 3 - Theoretical Framework, Section 4 - Research Method, Section 5 Results, Section 6 - Discussion, and Section 7 - Conclusion.

\section{THEORETICAL REVIEW}

Information asymmetry occurs when managers have more information than lenders to have a better picture of the company's actual value (Chou et al., 2011). A high level of information asymmetry affects shorter debt maturity (García-teruel et al., 2010). From a firm's perspective, (Flannery, 1986) argues that firms with a greater level of information asymmetry will tend to issue short-term debt because they face higher information costs, whereas firms with a lower level of information asymmetry will prefer long-term debt. From the lender's perspective, this information asymmetry can trigger adverse selection problems and moral hazard problems. Companies that are less transparent in disclosing information will be more likely to experience two problems of information asymmetry so that the cost of monitoring by lenders will be higher. Thus, creditors can use debt maturity when contracting debt to control the problem of information asymmetry (Ortiz-Molina and Penas, 2008; García-teruel et al., 2010).

In the context of information asymmetry and agency conflict, financial reporting and disclosure quality is one way to reduce adverse selection problems and moral hazard problems by improving the quality of contracts and monitoring (Healy and Palepu, 2001). 
(Bharath et al., 2008) found that a reduction in information risk perceived by lenders (due to a more accurate estimate of the firm's future cash flows) will encourage the adoption of shorter debt maturities. The company also gets incentives in the form of a decrease in the cost of borrowing when it can present higher quality earnings information (Valipour and Moradbeygi, 2011). (García-teruel et al., 2010) argued that firms with higher accrual quality could acquire debt with longer maturities. In addition, (VanKhanh and Hung, 2020) stated that a higher level of earnings quality positively affects the maturity level of corporate debt in Vietnam.

(Maurice et al., 2020) found that the level of corporate discretionary accruals has a negative effect on the debt maturity structure. Companies that practice earnings management through discretionary accruals (showing lower earnings quality) impact debt contracts granted by lenders. The results of this study are also in line with (Rey et al., 2020) and (De Meyere et al., 2018), which found that companies with higher earnings quality tend to have a larger proportion of long-term debt. The quality of earnings reported by the company will affect the quality of financial reporting as a whole. Higher earnings quality can reduce information asymmetry and agency problems between management and lenders. Creditor's assessment of the company's liquidity risk could be reduced. Creditors can then compensate for this lower information asymmetry with longer debt maturities. Based on the description above, the first hypothesis is formulated:

\section{H1: Earnings quality has a positive effect on debt maturity.}

The legitimacy of a company can be achieved by fostering strong relationships with stakeholders (Hahn and Lülfs, 2014). (Patten, 2002) reveals that voluntary disclosure of the information is seen as a means of gaining support from the community, proving that the company operates following social norms, maintaining a good image, and maintaining legitimacy. Companies that present IRs voluntarily seek to maintain and improve their legitimacy in the eyes of stakeholders (De Villiers et al., 2017). Disclosure of financial and non-financial performance information through IR will assist these different stakeholders in assessing the company's activities more efficiently and comprehensively.

IR presentation aims to present a holistic picture to investors of how non-financial capital is related to creating corporate financial value in one integrated report (Velte, 2021). In companies that present IR, good earnings quality can increase the company's ability to access loans with longer debt maturities. In addition, the application of IR presentation can be identified as a company legitimacy strategy (García-Sánchez et al., 2020). Companies that present IR can explain more comprehensively how the company's accrual policy can provide value to investors and creditors (Landau et al., 2020).

Research conducted by (Obeng et al., 2020) show that voluntary IR reporting as a disclosure mechanism positively influences the quality of reported earnings. In addition, the effect of IR presentation on earnings quality is more significant for companies that experience higher agency costs. In the context of information asymmetry and agency conflict, the higher the reported earnings quality of the company can encourage the company to obtain debt with a longer maturity (García-teruel et al., 2010). In addition, (VanKhanh and Hung, 2020), (Rey et al., 2020), and (De Meyere et al., 2018) that companies with higher earnings quality tend to have a more significant proportion of long- 
term debt. Therefore, the presentation of IR that can improve the quality of corporate reporting can moderate the effect of earnings quality on debt maturity.

Creditors see companies that present financial and non-financial information through IR to be more transparent in the management of their companies. The existence of voluntary disclosure of information through IRs can increase the company's legitimacy in the eyes of debt investors. This voluntary disclosure will encourage debt investors to assess that the company is trying to maintain its sustainability. Presentation of nonfinancial information through IR is expected to reduce information risk and company uncertainty. Based on the description above, the second hypothesis is formulated:

H2: Integrated Reporting strengthens the positive effect of earnings quality on debt maturity.

\section{METHODS}

This study employs a quantitative method. The sample selection in this study was carried out using a purposive sampling method based on several criteria. First, manufacturing companies that were consistently listed on the IDX during 2016-2020 presented complete financial statement data and annual reports related to the variables used in the study. The selection of this observation year is based on the implementation of the obligation to prepare an annual report by the Board of Directors as regulated in Per OJK No. 29/POJK.04/2016 and the enactment of PSAK 68 (2015) concerning Fair Value Accounting since 07 September 2015.

The selection of the manufacturing sector is based on several reasons. Manufacturing sector business processes which include the production of raw materials into finished goods, require significant investment in fixed assets (Scherr and Hulburt, 2014). In fulfilling that fixed-asset investment, the manufacturing sector uses funding through debt instruments. In the context of the manufacturing sector, increased use of debt can increase the company's financial leverage so that companies can generate profits and increase company growth more optimally (Surento and Fitriati, 2020). In addition, the manufacturing sector has fairly high debt and leverage ratio, so that determining debt maturity can affect the company's debt structure and investment risk (Hsb and Patrisia, 2020; Chandra et al., 2020).

Table 1. Research sample

\begin{tabular}{lr}
\hline \multicolumn{1}{c}{ Criteria } & Amount \\
\hline Manufacturing companies listed on the IDX as of July 2021 & 195 \\
Manufacturing companies listed on the IDX after January 1, 2015 & $(59)$ \\
Companies that do not present complete annual reports & $(15)$ \\
Companies that have incomplete data for the period 2016 s.d. 2020 & $(2)$ \\
Number of samples & 119 \\
Year & 5 \\
Total observations & 595 \\
\hline Source
\end{tabular}


The dependent variable used in this study is Debt Maturity (DM). Longer debt maturity can minimize the company's default risk by minimizing liquidity risk (Surasmi et al., 2020). Meanwhile, short-term debt allows lenders to review their loan decisions more frequently and limit debtor flexibility which can increase asset risk (Maurice et al., 2020). Companies with a greater level of information asymmetry will tend to issue short-term debt because they face greater information costs, while companies with a lower level of information asymmetry will choose long-term debt (Flannery, 1986). Therefore, the greater the proportion of long-term debt in a company, it can be interpreted as a better creditor assessment of the company's liquidity risk.

To measure debt maturity, the authors use models from previous studies such as in the research of (VanKhanh and Hung, 2020), (Rey et al., 2020), (Maurice et al., 2020), (Olibe et al., 2019), and (De Meyere et al., 2018). DM is calculated as the ratio of longterm debt (more than one year) compared to total debt (sum of short-term debt and longterm debt). A higher DM value indicates a lower information asymmetry so that lenders are willing to provide debt with a longer maturity. The following formula measures the DM:

$$
\mathrm{DM}=\frac{\text { Long term liabilities }}{\text { Total liabilities }}
$$

Earnings quality (EQ) refers to the ability of earnings reported in the financial statements to reflect the company's actual earnings, as well as the ability to predict future earnings (Bharath et al., 2008). EQ also refers to the stability and persistence of reported earnings (VanKhanh and Hung, 2020). Higher earnings quality provides more information about a company's financial performance features relevant to certain decisions made by decision-makers (Dechow et al., 2010).

Earnings quality is measured using (Kothari et al., 2005) model. The model was chosen because ADA (Absolute of Performance-Adjusted Discretionary Accruals) can capture management actions related to discretionary accruals on financial statements (Mahari and Purwanto, 2016). The model can also provide better explanatory power in detecting indications of earnings management that can affect earnings quality (Cespa, 2008). The following formula measures the EQ:

$$
\frac{T A C C_{i t}}{T A_{i t-1}}=\beta_{1} \frac{1}{T A_{i t-1}}+\beta_{2} \frac{\Delta R E V_{i t}}{T A_{i t-1}}+\beta_{3} \frac{P P E_{i t}}{T A_{i t-1}}+\beta_{4}\left(R O A_{i t-1}\right)+\varepsilon_{i t}
$$

Where,

TACCit = net income - operating cash flow of the company $\mathrm{i}$ in year $\mathrm{t}$

TAit-1 = total asset of the company $\mathrm{i}$ in the previous year

$\triangle$ REVit $\quad=$ changes in revenue of the company $i$ in year $t$ and $t-1$

PPEit = net value of plant, property, and equipment company $\mathrm{i}$ in year $\mathrm{t}$

ROAit-1 = return on asset of the company $i$ in the previous year

cit $\quad=$ discretionary accrual of the company $\mathrm{i}$ in the previous year $(\mathrm{DAi}, \mathrm{t})$ 
To determine DA, the regression will be cross-sectionally first for each year starting from 2016 to 2020 . The TACC value above must be defined first for the regression to be carried out (Kothari et al., 2005). The following equation determines the TACC value:

Where:

$$
T A C C_{i t}=N I_{i t}-C_{i t}
$$

$\mathrm{NI}_{\mathrm{i}, \mathrm{t}} \quad=$ net income company $\mathrm{i}$ in year $\mathrm{t}$

$\mathrm{CFO}_{\mathrm{i}, \mathrm{t}}=$ operating cash flow company $\mathrm{i}$ in year $\mathrm{t}$

Absolute performance-adjusted discretionary accruals (ADA) is the absolute value of the residual $(\varepsilon i, t)$ from the estimation results of the above equation according to the research of (Rey et al., 2020) and (García-teruel et al., 2010). The absolute value of discretionary accruals shows that upward and downward adjustments of reported earnings are considered earnings management that reduces the quality of reported earnings (Fung and Goodwin, 2013). The greater the value of ADA, the higher the discretionary accruals, indicating the lower earnings quality.

This study uses Integrated Reporting (IR) as a moderator variable. The IR disclosure variable will be measured based on the conformity of the information disclosure in the company's annual report with the IR Framework by the IIRC (International Integrated Reporting Council). Based on the framework issued by IIRC in 2013, there are eight main measurement dimensions, namely the description of the organization and the external environment, organizational governance, business models, risks and opportunities, strategy and allocation, performance, prospects, and the basis for disclosure of elements (IIRC, 2013). Measurement of this variable will be done by content analysis. This study will use an IR checklist based on the 2013 IR framework as in the research of (Herath and Gunarathne, 2016), (Tesalonika, 2020), (Jayasiri, 2020), and (Cooray et al., 2021). The measurement of the IR variable is carried out by giving a score of 1 if the company discloses the elements of each IR content element according to the checklist and 0 if it does not disclose. After measuring the score for the disclosure of IR content elements, the scores will be added and divided by the maximum value to obtain the level of disclosure of IR elements for each company. Integrated reporting variable indicators for each company are obtained from the following formula.

$$
I R_{i t}=\frac{\text { Total score disclosed by the company }}{\text { Total number of criteria in the IR framework guidelines }}
$$

In this study, three control variables are used, size, leverage, and asset maturity. The firm size is measured by the natural logarithm proxy (ln) of total assets. This proxy is following (VanKhanh and Hung, 2020), (Rey et al., 2020), and (Van et al., 2019). Leverage shows how much equity is available to provide guarantees for debt. In this study, leverage is defined as the ratio of total debt to total assets in year $t$ following (Maurice et al., 2020), (VanKhanh and Hung, 2020), and (Rey et al., 2020). Asset maturity is a weighted average of fixed asset maturity. Asset maturity is used to control the negative relationship between assets with long-term maturity and short-term debt. Meanwhile, in this study, the firm's asset maturity variable was measured using the research model of 
(García-teruel et al., 2010), (Maurice et al., 2020), (VanKhanh and Hung, 2020), and (Rey et al., 2020).

Model 1 is used to examine the effect of earnings quality on debt maturity.

$$
D M_{i t}=\beta_{0}+\beta_{1} E Q_{i t}+\beta_{2} L E V_{i t}+\beta_{3} S I Z E_{i t}+\beta_{4} \mathrm{AM}_{i t}+\varepsilon_{i t}
$$

Meanwhile, to analyze the role of Integrated Reporting in moderating the effect of the tested independent variables on debt maturity, model 2 is used as follows.

$$
\begin{gathered}
D M_{i t}=\beta_{0}+\beta_{1} E Q_{i t}+\beta_{2} L E V_{i t}+\beta_{3} S I Z E_{i t}+\beta_{4} \mathrm{AM}_{i t} \\
+\beta_{5} I R_{i t}+\beta_{6}\left(E Q_{i t} * \mathrm{IR}_{i t}\right)+\varepsilon_{i t}
\end{gathered}
$$

Where,

$\mathrm{DM}_{\mathrm{it}}=$ debt maturity of firm $\mathrm{i}$ in year $\mathrm{t}$

$\mathrm{EQ}_{\mathrm{it}} \quad=$ earnings quality of firm $\mathrm{i}$ in year $\mathrm{t}$

$\mathrm{IR}_{\text {it }} \quad=$ Integrated Reporting disclosure index of firm $\mathrm{i}$ in year $\mathrm{t}$

$\mathrm{LEV}_{\text {it }}=$ leverage of firm i year $\mathrm{t}$ scaled by total assets

SIZE $_{i t}=$ firm size $\mathrm{i}$ in year $\mathrm{t}$

$\mathrm{AM}_{\mathrm{it}}=$ maturity of firm i's assets in year $\mathrm{t}$

\section{RESULTS}

Descriptive statistics for the variables in this study are listed in Table 2.

Table 2. Descriptive Statistics

\begin{tabular}{ccccccc}
\hline Variabel & Obs. & Mean & Med & Max & Min. & Std. Dev \\
\hline DM & 595 & 0.3246 & 0.2914 & 0.2193 & 0.9727 & 0.0000 \\
ADA & 595 & 0.0603 & 0.0461 & 0.0533 & 0.3207 & 0.0000 \\
IR & 595 & 0.5850 & 0.5658 & 0.1123 & 0.9079 & 0.3421 \\
SIZE & 595 & 28.7155 & 28.4822 & 1.5972 & 33.4945 & 25.2156 \\
LEV & 595 & 0.5431 & 0.4778 & 0.5394 & 5.1677 & 0.0119 \\
AM & 595 & 8.0969 & 5.9548 & 9.7915 & 121.7468 & 0.5417 \\
\hline
\end{tabular}

Source: Authors

Furthermore, the results of regression model selection tests (Chow test, Lagrange multiplier test, Hausman test) suggest that the most appropriate regression model in this research is a random-effect model (REM). The result of equation model regression is as follows: 
Table 3. Equation model regression test results

\begin{tabular}{|c|c|c|c|c|c|c|c|}
\hline \multirow{2}{*}{ Variable } & \multirow{2}{*}{ Sign } & \multicolumn{3}{|c|}{ Model 1} & \multicolumn{3}{|c|}{ Model 2} \\
\hline & & Koef. & t-Stat & Prob. & Koef. & $\mathrm{t}$-Stat & Prob. \\
\hline $\mathrm{C}$ & & -0.502 & -1.828 & 0.034 & -0.462 & -1.533 & 0.063 \\
\hline $\mathrm{ADA}$ & - & 0.030 & 0.148 & 0.441 & -0.455 & -0.454 & 0.324 \\
\hline SIZE & & 0.030 & 3.220 & $0.001 * * *$ & 0.029 & 2.799 & $0.002 * * *$ \\
\hline LEV & & -0.001 & -0.061 & 0.477 & -0.013 & -0.545 & 0.297 \\
\hline $\mathrm{AM}$ & & 0.001 & 1.919 & $0.002 * * *$ & 0.002 & -2.726 & $0.001 * * *$ \\
\hline IR & & & & & -0.125 & -0.675 & 0.249 \\
\hline ADA*IR & - & & & & 1.137 & 0.658 & 0.255 \\
\hline R-Squared & & & & 0.0252 & & & 0.0487 \\
\hline $\begin{array}{l}\text { Adj. } \\
\text { Squared }\end{array}$ & & & & 0.0170 & & & 0.0319 \\
\hline F-Statistic & & & & 5.5853 & & & 2.8928 \\
\hline $\begin{array}{l}\text { Prob. (F- } \\
\text { Statistic) }\end{array}$ & & & & 0.0000 & & & 0.0058 \\
\hline
\end{tabular}

To elaborate on the effect of earnings quality on debt maturity, this study performs additional analysis to understand the difference in the effect of companies that tend to do earnings management by increasing profits (income maximization) with companies that tend to reduce profits (income minimization). The additional analysis was carried out by separating companies with positive DA values and negative DA values. Companies with a positive DA value indicate companies that tend to do income maximization. Meanwhile, a company with a negative DA value means that the company tends to do income minimization. After being separated based on the DA value, the data was performed Ordinary Least Square (OLS) regression using the EViews 9 application. The results of these additional tests are shown in Table 4 as follows.

Table 4. Additional Test

\begin{tabular}{|c|c|c|c|c|c|c|c|c|c|c|c|c|}
\hline \multirow{3}{*}{ Var. } & \multicolumn{6}{|c|}{ Income Maximization $(\mathrm{n}=192)$} & \multicolumn{6}{|c|}{ Income Minimization $(\mathrm{n}=403)$} \\
\hline & \multicolumn{3}{|c|}{ Model 1} & \multicolumn{3}{|c|}{ Model 2} & \multicolumn{3}{|c|}{ Model 1} & \multicolumn{3}{|c|}{ Model 2} \\
\hline & Koef & t-Stat & Prob & Koef & t-Stat & Prob & Koef & t-Stat & Prob & Koef & t-Stat & Prob \\
\hline $\mathrm{C}$ & -0.37 & -1.06 & 0.14 & -0.28 & -0.79 & 0.21 & -0.47 & -1.57 & 0.05 & -0.46 & -1.53 & 0.06 \\
\hline ADA & -0.39 & -2.01 & 0.01 & -1.73 & -2.32 & 0.01 & 0.22 & 1.20 & 0.11 & -0.45 & -0.45 & 0.32 \\
\hline SIZE & 0.02 & 1.93 & 0.02 & 0.02 & 1.69 & 0.04 & 0.02 & 2.71 & 0.00 & 0.02 & 2.79 & 0.00 \\
\hline LEV & 0.04 & -0.97 & 0.41 & -0.01 & -0.25 & 0.39 & -0.01 & -0.55 & 0.29 & -0.01 & -0.54 & 0.30 \\
\hline $\mathrm{AM}$ & 0.00 & 2.31 & 0.09 & 0.00 & 2.21 & 0.01 & 0.00 & 3.03 & 0.00 & 0.00 & 2.96 & 0.00 \\
\hline IR & & & & -0.06 & -0.32 & 0.37 & & & & -0.12 & -0.67 & 0.24 \\
\hline ADA*IR & & & & 2.16 & 1.68 & 0.04 & & & & 1.13 & 0.65 & 0.25 \\
\hline $\mathbf{R}^{2}$ & & & 0.0666 & & & 0.0805 & & & 0.0473 & & & 0.1380 \\
\hline $\operatorname{Adj} . R^{2}$ & & & 0.0466 & & & 0.0507 & & & 0.0353 & & & 0.1160 \\
\hline F-Stat & & & 3.3374 & & & 2.7026 & & & 3.9442 & & & 6.2789 \\
\hline $\begin{array}{l}\text { Prob. (F- } \\
\text { Stat) }\end{array}$ & & & 0.0000 & & & 0.0000 & & & 0.0016 & & & 0.0000 \\
\hline
\end{tabular}

Source: Authors 


\section{DISCUSSION}

The effect of earnings quality on debt maturity. Based on the results of hypothesis testing, earnings quality does not affect the maturity of the company's debt. The results of this study are not in line with several previous studies which state that earnings quality has a positive effect on debt maturity (Maurice et al., 2020; De Meyere et al., 2018; Garcíateruel et al., 2010). The difference in the results of this study can be caused by differences in the sample companies used. The research of (Maurice et al., 2020), (De Meyere et al., 2018), and (García-teruel et al., 2010) use company data in Europe where the characteristics of developed companies can be different from developing countries such as Indonesia. Although this research and (VanKhanh and Hung, 2020) were conducted in developing countries, namely Indonesia and Vietnam, the results differed. These differences in results can be caused by differences in the proxies used because (VanKhanh and Hung's, 2020) research measures earnings quality using the (Dechow and Dichev, 2002) model, while this study employs the performance-matched discretionary accruals model by (Kothari, 2005).

Based on agency theory, good quality of earnings information can reduce information asymmetry between managers and creditors, thereby increasing management monitoring and increasing the maturity of the company's debt (García-teruel et al., 2010). This reduction in information asymmetry can facilitate oversight of corporate managers by creditors and encourage less need for short-term debt. However, the results of this study do not confirm the agency theory in the context of manufacturing companies in Indonesia.

Three mechanisms can reduce the problem of information asymmetry arising from debt contracts: reducing the amount of debt, using faster debt maturity, or more restrictive covenant requirements (Barclay and Smith, 1995). From the results of this study, creditors are likely to use other debt contract instruments to reduce information asymmetry problems, such as through stricter debt covenant requirements or larger collateral requests.

Manufacturing companies are companies that process raw materials and produce them into finished products. One of the characteristics of a manufacturing company is that it requires a large enough capital to carry out the production process. In addition, investment projects in manufacturing companies tend to take a long time. To finance it, manufacturing companies can obtain funds from external sources in the form of debt. Manufacturing companies that are the sample of this study have an average debt to asset ratio of $54.31 \%$. The capital structure of manufacturing companies still requires funding from debt. Therefore, managers of manufacturing companies will try to make it easier for companies to access debt financing more efficiently.

On the other hand, creditors will assess the company's credit risk based on the quality of the company's reported earnings (Maurice et al., 2020). Companies will have lower credit risk when reporting income that is more information about future economic performance (Saksessia and Firmansyah, 2020). This lower credit risk gives managers have an incentive to report higher quality earnings because it can reduce the company's borrowing costs (Ghosh and Moon, 2010).

Manufacturing companies in Indonesia have good debt policy management so that creditors tend not to respond to accrual earnings management information carried out by companies through lower debt maturities (Mukhibad et al., 2020). With the dominant long-term investment characteristics (Maulita and Tania, 2018), manufacturing companies 
also have relatively large fixed assets compared to other sectors to collateral company debt. Therefore, creditors may prefer to use collateral or restrictive covenant instruments to reduce borrowers' credit risk while providing long-term debt to manufacturing companies. Creditors will use information regarding the quality of the company's earnings to evaluate the suitability of the company's performance against the debt covenant or to evaluate the present value of the assets guaranteed as collateral.

This study also conducted additional tests to further elaborate on the cause of the non-influence of earnings quality on debt maturity. The additional test is carried out by separating companies with a positive DA (discretionary accruals) value and a negative DA value before being absolute. A positive DA value indicates accrual earnings management actions that aim to increase company profits (income maximization). While the negative DA value means the company tends to try to reduce profits (income minimization). Of the 595 observational data, 192 observational data indicate that the company increases profits through accrual earnings management. Meanwhile, 403 other observational data are companies that tend to reduce profits through accrual earnings management. In proportion, the number of companies that tend to reduce profits (income minimization) is more than twice as large as companies that increase profits.

Based on the additional regression test results in Table 4, companies that tend to reduce profits (income minimization) have no significant effect on debt maturity. The dominance of a large amount of company observation data that reduces profits can cause the ineffectiveness of earnings quality on debt maturity. However, companies that increase earnings (income maximization) through accrual earnings management have a significant negative effect on debt maturity. These findings indicate that the response of creditors to the accrual earnings management of borrowing companies is different.

Companies that seek to increase profits (income maximization) through accrual earnings management are judged by creditors as opportunistic management actions that can reduce the quality of the company's earnings. Earnings information that tends to be larger than it should be can lead to higher future cash flow volatility so that it can pose a risk to the company's ability to pay interest and principal debt (Goyal and Wang, 2013). Managers of companies that carry out income maximization tend to be motivated to avoid violations of long-term debt contracts (debt covenants) (Dichev and Skinner, 2002). Therefore, creditors will tend to be more careful in entering into debt contracts with these companies; one way is through lower debt maturity. The short-term debt can be used as a supervisory tool for creditors because creditors can more often evaluate credit risk and company performance during the debt refinancing process.

Companies involved in accrual earnings management to increase profits have a greater incentive to issue long-term maturity debt so that managers can reduce the frequency of monitoring from creditors relative to short-term debt. Creditors will tend to be more careful in processing and analyzing accounting information that can be manipulated by companies that carry out income maximization. As a result, creditors compensate for the risk of weakness in the quality of the company's financial reporting by providing short-term debt to increase more routine monitoring and evaluation.

Based on the description above, information regarding earnings quality is not responded to by creditors by changing the maturity of the debt. However, it will be used to evaluate the suitability of the company's performance against the debt covenant or to evaluate the present value of the assets used as collateral. Furthermore, company managers 
who maximize income tend to be motivated to avoid violating long-term debt contracts (debt covenants). Earnings information that tends to be larger than it should be can lead to higher future cash flow volatility. Therefore, creditors will tend to increase their supervision through lower debt maturities.

The moderation role of Integrated Reporting on the association between earnings quality and debt maturity. Based on the results of hypothesis testing, the presentation of IR cannot moderate the effect of earnings quality on debt maturity. The results of this study are not in line with previous research, which states that by presenting IR, companies with better earnings quality will have a lower cost of debt, one of which is through longer debt maturities (Muttakin, 2020). Differences in the results of these studies can be caused by differences in company data used. (Muttakin's, 2020) uses data from the United States where the characteristics of disclosure of IR elements by companies in developed countries will be different from developing countries such as Indonesia.

Based on the theory of legitimacy, corporate transparency and disclosure of financial and non-financial information through IR is carried out by companies in order to be able to manage sustainable organizational legitimacy from time to time waktu (García-Sánchez et al., 2020). The company discloses this information to justify the company's activities, including earnings management carried out by management. However, companies that present IR tend to carry out a manipulative legitimacy strategy (manipulation of legalization strategy). The application of IR is made only to show that the company is initiative and adaptive to developing reporting issues without understanding the value of IR itself (Tang, 2017).

Based on the results of this study, the disclosure of IR elements in manufacturing companies in Indonesia has an average of 56.7\%. These findings are not much different from the research of (Chariri and Januarti (2017), which found an average disclosure of the IR elements of companies in Indonesia at 51\%, and (Kustiani, 2017), which found the application of the IR elements on average $63.8 \%$. The high level of disclosure of IR elements in Indonesia maybe since several IR elements have become components that must be presented in the company's annual reporting based on the Decree of the Chairman of Bapepam and LK Number: Kep-431/BL/2012 concerning Submission of Annual Reports of Issuers or Public Companies. However, the voluntary disclosure of information through the IR does not value investors and creditors in Indonesia (Khairina, 2018). IR adoption also does not affect the value relevance of accounting information (Fernando et al., 2018). In addition, IR reporting cannot influence investors in making investment decisions so that it does not affect the stock prices of manufacturing companies in Indonesia (Mipo, 2020; Sebayang et al., 2021).

In the Indonesian context, companies that present information through IR are still mimetic isomorphism where the company duplicates the practices of other companies to get the same competitive advantage from presenting IR (Chariri, 2019). These characteristics are similar to companies in other developing countries such as Sri Lanka, which initially adopted IR only for rhetorical purposes without understanding the value of implementing IR itself other than only for reporting mechanisms (Gunarathne and Senaratne, 2017). In contrast to more developed countries, companies in Europe that implement IR are primarily of moderate and high quality. This could be due to the greater commitment of European companies to transparency due to cultural and regulatory 
factors. For example, regulations governing the disclosure of non-financial information by companies in Directive 2014/05/EU of the European Parliament and the Council (Eccles et al., 2019).

Meanwhile, the application of IR in US companies tends to be low because the legal environment is more rules-based. The sizeable gap in the quality of IRs worldwide indicates that there is still no generally accepted standard for applying IRs, leaving companies free to self-claim that they have issued IRs when these companies are still experiencing misconceptions implementing IRs (Eccles et al., 2019).

Although the initial goal of IR is to become a single report that can facilitate the information needs of stakeholders, there is no obligation for companies to present IR as the company's main report (Flower, 2015). In addition, the IR framework does not impose sanctions when companies do not conclusively disclose information under the IR framework. The concept of IR is also based on principle-based where the manager's judgment will affect the quality of information presented through IR. The amount of professional judgment that underlies the preparation of the IR can cause neutrality problems. In the absence of consensus on the standard level of interpretation of IR principles and assurance from other parties, the company's disclosure of information through IR can be a unilateral claim (Cheng et al., 2014). Companies can intentionally use IR reporting as a medium to gain legitimacy for their activities (Chariri, 2019). Therefore, creditors, as one of the IR users, find it difficult to verify the information disclosed by the company.

IR reporting is a relatively new concept, companies that adopt IR still implement the process by trial and error to increase the cost of implementing IR. In addition, the existence of separate disclosures such as ESG and CSR reports can reduce the added value of IRs (Maniora, 2017). This information overload causes creditors and investors not to understand the purpose of disclosing information through IRs. In addition, the perception gap arises because the company itself does not fully understand what information is needed by stakeholders (Naynar et al., 2018). Users of integrated reports such as creditors still need additional information on competence, management performance, and corporate governance to ensure financial sustainability and corporate credit risk.

In its implementation, there are several obstacles in the broad implementation of IR practices, such as the concept of value creation and integrated thinking, which is still unclear, the possibility of using IR as mere reporting rhetoric, and regulations that are still lacking to encourage IR implementation (Dumay et al., 2017). The complexity of implementing IR makes understanding of IR still relatively low, both from company management, IR reporting makers to IR users themselves. In the Indonesian context, corporate report makers, academics, and OJK employees still have a limited understanding of IR's concept and practical implementation in Indonesia (Adhariani and Villiers, 2018). The preparers of the company's financial statements stated that they could see the benefits of IR, but they were reluctant to implement it. These barriers may be due to factors such as the level of stakeholder demand for IRs that are still lacking, the availability of professional accountants who understand the concept of IR, and cultural and regulatory support that is not yet available (Navarrete-Oyarce et al., 2021).

The common understanding of the concept of IR by report makers and IR users, the adoption of IR by companies in Indonesia is only for reporting mechanisms, and the absence of regulations, incentives, and sanctions to apply IR can cause disclosure of 
information through IR has not been able to respond by creditors in assessing the quality of financial statements when contracting debt.

\section{CONCLUSION}

This study found that earnings quality does not affect debt maturity. Earnings information is not responded to by creditors by changing the maturity of the debt but with other debt contract instruments such as debt covenants and collateral. Information regarding the quality of the company's earnings will be used to evaluate the suitability of the company's performance against the debt covenant or to evaluate the present value of the assets pledged as collateral. Additional tests conducted show that companies that tend to increase profits (income maximization) have a negative effect on debt maturity. Managers of companies that maximize income profit tend to be motivated to avoid violations of long-term debt contracts (debt covenants). Earnings information that tends to be larger than it should be can lead to higher future cash flow volatility. Therefore, creditors will tend to increase their supervision through lower debt maturities.

Furthermore, the result of the study indicates that Integrated Reporting failed to moderate the effect of earnings quality on debt maturity. The presentation of IR can be a manipulation of legalization strategy and unilateral claims by the company. Report makers and IR users' common understanding of the IR concept makes it difficult to implement IR. The adoption of IR by companies in Indonesia is only for reporting mechanisms, and there are no regulations, incentives, and sanctions for implementing IR. Therefore, creditors cannot assess the quality of IR presentation and respond to information in the IR when entering into debt contracts with the company.

The limitation of this research is the measurement of the IR variable index score using the company's annual report data with the content analysis method. The process of measuring the index, which is carried out independently, can lead to subjective assessment. This study was only conducted on manufacturing companies listed on the IDX, so that the results of this study cannot be used to generalize the behavior of all public companies in Indonesia. This study also does not consider other debt contract instrument factors when testing debt maturities, such as the existence of debt covenants and collateral.

Future research can use companies in sectors other than manufacturing in order to explain the nature of the research variables on companies in other sectors. The literature on the attributes of debt contracts in Indonesia is still rarely reviewed. Past research has often involved trade-offs between different elements of debt contractual agreements. Future research can further investigate whether the variables in this study affect other elements of debt contracts and how debt maturity interacts with restrictive covenants and collateral in the framework of drafting debt contracts. Future research can further explore how company-specific characteristics and macroeconomic factors can influence or moderate the effect of the variables in this study on debt maturity in Indonesia. In addition, further research can distinguish private debt and public debt to better understand the characteristics of debt maturity and its impact on companies and creditors.

Based on the results of this research, creditors, as one of the primary providers of funds for companies, assess the quality of financial statement information when contracting debt, especially company profit information. Companies need to reduce discretionary accrual policies through income maximization because it impacts reducing 
creditors' trust to provide long-term debt. Besides, creditors and investors can consider the maturity of the debt in making investment decisions. Creditors can consider this information when making loans to companies that have more short-term debt. In addition, investors can also consider information about debt maturity to choose which company has lower investment risk.

Financial Services Authority needs to analyze and evaluate the effectiveness of policies, regulations, practices, and business processes in the capital and debt markets. The study results can provide input that disclosure of information regarding debt maturity policies and other debt contract instruments needs to be submitted so that investors and creditors can better assess the company's credit risk. With the growing trend of holistic reporting through IR and its positive impact on increasing creditor protection in Indonesia, the government should encourage the implementation of IR by companies through regulations or incentives for companies that will adopt IR. In the future, the government and related parties can increase understanding through IR training, such as teaching, seminars, conferences, and the inclusion of IR in university curricula to educate current and future report makers and stakeholders. In addition, existing policies such as Per OJK No. 29/POJK.04/2016 Concerning the Annual Report of Issuers or Public Companies needs to be re-evaluated to add the concept of integrated thinking in presenting the annual report.

\section{REFERENCES}

Adachi-Sato, M., and Vithessonthi, C. (2019). Corporate debt maturity and future firm performance volatility. International Review of Economics and Finance, 60, 216237. https://doi.org/10.1016/j.iref.2018.11.001.

Almeida, H., Murillo, C., Bruno, L., and Scott, W. (2011). Corporate Debt Maturity and the Real Effects of the 2007 Credit Crisis. Critical Finance Review, 1(1), 3-58. https://doi.org/10.1561/103.00000001.

Barclay and Smith (1995). The Maturity Structure of Corporate Debt. The Journal of Finance, 50(2), 609-631. https://doi.org/10.1111/j.1540-6261.1995.tb04797.x.

Bharath, S. T., Sunder, J., and Sunder, S. V. (2008). Accounting quality and debt contracting. The Accounting Review, 83(1), 1-28.

Brunnermeier, M. K., and Oehmke, M. (2013). The maturity rat race. The Journal of Finance, 68(2), 483-521.

Casino-Martínez, A., López-Gracia, J., Mestre-Barberá, R., and Peiró-Giménez, A. (2019). An agency approach to debt maturity of unlisted and listed firms in the European setting. European Management Journal, 37(3), 339-352. https://doi.org/10.1016/j.emj.2018.07.008.

Chandra, A., Wijaya, F., Hayati, K., dan Indonesia, U. P. (2020). Pengaruh Debt to Equity Ratio, Total Assets Turnover, Firm Size, dan Current Ratio terhadap Return on Assets ( The Effects of the Debt to Equity Ratio, Total Assets Turnover, Firm Size , and Current Ratio on Return on Assets ). Jurnal Akuntansi, Keuangan, Dan Manajemen (Jakman), 2(1), 57-69.

Chariri, A., dan Januarti, I. (2017). Eksplorasi Elemen Integrated Reporting Dalam Annual Reports Perusahaan Di Indonesia. Jurnal Akuntansi, 21(3), 411. https://doi.org/10.24912/ja.v21i3.245. 
Chen, H., Xu, Y., and Yang, J. (2021). Systematic risk, debt maturity, and the term structure of credit spreads. Journal of Financial Economics, 139(3), 770-799. https://doi.org/10.1016/j.jfineco.2020.09.002.

Cooray, T., Senaratne, S., Gunarathne, N., Herath, R., and Samudrage, D. N. (2021). Adoption of integrated reporting in Sri Lanka: coverage and trend. Journal of Financial Reporting and Accounting.

Cortesi, A., and Vena, L. (2019). Disclosure quality under integrated reporting: A Value Relevance Approach. Journal of Cleaner Production, 220, 745-755.

De Meyere, M., Vander Bauwhede, H., and Van Cauwenberge, P. (2018). The impact of financial reporting quality on debt maturity: the case of private firms. Accounting and Business Research, 48(7), 759-781. https://doi.org/10.1080/00014788.2018.1431103.

Dechow, P., Ge, W., and Schrand, C. (2010). Understanding earnings quality: A review of the proxies, their determinants and their consequences. Journal of Accounting and Economics, 50(2-3), 344-401.

Della Seta, M., Morellec, E., and Zucchi, F. (2020). Short-term debt and incentives for risk-taking. Journal of Financial Economics, 137(1), 179-203. https://doi.org/10.1016/j.jfineco.2019.07.008.

Di Vaio, A., Syriopoulos, T., Alvino, F., and Palladino, R. (2020). "Integrated thinking and reporting" towards sustainable business models: a concise bibliometric analysis. Meditari Accountancy Research.

Dichev, I. D., and Skinner, D. J. (2002). Large-sample evidence on the debt covenant hypothesis. Journal of Accounting Research, 40(4), 1091-1123. https://doi.org/10.1111/1475-679X.00083.

Do, T. K. (2020). Financial statement comparability and corporate debt maturity. Finance Research Letters, March, 101693. https://doi.org/10.1016/j.frl.2020.101693.

Eccles, R. G., Krzus, M. P., and Solano, C. (2019). A Comparative Analysis of Integrated Reporting in Ten Countries. SSRN Electronic Journal. https://doi.org/10.2139/ssrn.3345590.

Farhi, E., and Tirole, J. (2012). Collective Moral Hazard, Maturity Mismatch, and Systemic Bailouts. The American Economic Review, 102(1), 60-93. http://www.jstor.org/stable/41408769.

Flower, J. (2015). The international integrated reporting council: A story of failure. Critical Perspectives on Accounting, 27, 1-17. https://doi.org/10.1016/j.cpa.2014.07.002.

Fung, S. Y. K., and Goodwin, J. (2013). Short-term debt maturity, monitoring and accruals-based earnings management. Journal of Contemporary Accounting and Economics, 9(1), 67-82. https://doi.org/10.1016/j.jcae.2013.01.002.

García-Sánchez, I. M., Raimo, N., Marrone, A., and Vitolla, F. (2020). How does integrated reporting change in light of COVID-19? A revisiting of the content of the integrated reports. Sustainability (Switzerland), 12(18). https://doi.org/10.3390/su12187605.

García-teruel, P. J., Martínez-Solano, P., and Sánchez-Ballesta, J. P. (2010). Accruals quality and debt maturity structure. Abacus, 46(2), 188-210. https://doi.org/10.1111/j.1467-6281.2010.00312.x.

Ghanbari, M., Hayati, E., Taheri, M., and Kaki, M. (2018). Evaluating the impact of fair 
value accounting on debt structure and financial reporting of listed companies in Tehran Stock Exchange. 0-4.

Gong, Y., and Wei, X. (2019). Asset quality, debt maturity, and market liquidity. Finance Research Letters, 31, 285-293. https://doi.org/10.1016/j.frl.2018.11.015.

Goyal, V. K., and Wang, W. (2013). Debt maturity and asymmetric information: Evidence from default risk changes. Journal of Financial and Quantitative Analysis, 48(3), 789-817. https://doi.org/10.1017/S0022109013000240.

Grassmann, M. (2021). The relationship between corporate social responsibility expenditures and firm value: The moderating role of integrated reporting. Journal of Cleaner Production, 285, 124840. https://doi.org/10.1016/j.jclepro.2020.124840.

Habib, A., and Costa, M. D. (2021). Debt maturity structure and cost stickiness. Journal of Corporate Accounting \& Finance, 32(1), 78-89. https://doi.org/10.1002/jcaf.22479

Hahn, R., and Lülfs, R. (2014). Legitimizing negative aspects in GRI-oriented sustainability reporting: A qualitative analysis of corporate disclosure strategies. Journal of Business Ethics, 123(3), 401-420.

Herath, and Gunarathne. (2016). Assessing the gap between integrated reporting and current integrated corporate reporting practice: a proposed checklist. 11th Faculty of Management Studies and Commerce (FMSC) Research Symposium, August, 40-52. https://doi.org/10.13140/RG.2.2.30407.91048.

Hsb, K. N., and Patrisia, D. (2020). The Effect of Corporate Debt Maturity on Performance Volatility in Manufacturing Companies Listed on the Indonesia Stock Exchange in 2014-2018. 152(2016), 475-486.

IIRC. (2013). The International Integrated Reporting Framework. https://doi.org/10.1254/fpj.71.757.

Jayasiri, N. K. (2020). Integrated reporting in Sri Lanka: An exploratory study. University of Otago.

Jensen, M. C., and Meckling, W. H. (1976). Theory of the firm: Managerial behavior, agency costs and ownership structure. Journal of Financial Economics, 3(4), 305360.

Jordan, C. O. F. (2018). the Determinants of Debt Maturity : the. 22(1), 1-13.

Jungherr, J., and Schott, I. (2020). Optimal debt maturity and firm investment. Review of Economic Dynamics, 1, 1-23. https://doi.org/10.1016/j.red.2020.10.005.

Kashefi Pour, E., and Lasfer, M. (2019). Taxes, governance, and debt maturity structure: International evidence. Journal of International Financial Markets, Institutions and Money, 58, 136-161. https://doi.org/10.1016/j.intfin.2018.09.011.

Kothari, S. P., Leone, A. J., and Wasley, C. E. (2005). Performance matched discretionary accrual measures. Journal of Accounting and Economics, 39(1), 163-197. https://doi.org/10.1016/j.jacceco.2004.11.002.

Kustiani, N. A. (2017). Penerapan Elemen-Elemen Integrated Reporting Pada Perusahaan Yang Terdaftar Di Bursa Efek Indonesia. Info Artha, 3, 44-61. https://doi.org/10.31092/jia.v3i0.38.

Lai, A., Melloni, G., and Stacchezzini, R. (2016). Corporate Sustainable Development: Is "Integrated Reporting" a Legitimation Strategy? Business Strategy and the Environment, 25(3), 165-177. https://doi.org/10.1002/bse.1863.

Mahari, A. P., dan Purwanto, A. (2016). Pengaruh Dividen Dan Status Pembayaran Dividen Tunai Terhadap Kualitas Laba Perusahaan (Studi Empiris Pada Perusahaan 
Manufaktur Yang Terdaftar Di Bursa Efek Indonesia Pada Tahun 2010-2014). Diponegoro Journal of Accounting, 5(3), 11-21.

Manuelli, R. E. (2019). What determines debt maturity? Federal Reserve Bank of St. Louis Review, 101(3), 155-176. https://doi.org/10.20955/r.101.155-76.

Maurice, Y., Mard, Y., and Séverin, É. (2020). The effect of earnings management on debt maturity: An international study. Comptabilite Controle Audit, 26(2), 125-156. https://doi.org/10.3917/cca.262.0125.

Modigliani, F., and Miller, M. H. (1958). The cost of capital, corporation finance and the theory of investment. The American Economic Review, 48(3), 261-297.

Modigliani, F., and Miller, M. H. (1963). Corporate income taxes and the cost of capital: a correction. The American Economic Review, 53(3), 433-443.

Myers, S. C. (1977). Determinants of corporate borrowing. Journal of Financial Economics, 5(2), 147-175.

Myers, S. C. (1984). Finance theory and financial strategy. Interfaces, 14(1), 126-137.

Navarrete-Oyarce, J., Gallegos, J. A., Moraga-Flores, H., and Gallizo, J. L. (2021). Integrated reporting as an academic research concept in the area of business. Sustainability (Switzerland), 13(14), 17-19. https://doi.org/10.3390/su13147741.

Nguyen, V. H., Choi, B., and Agbola, F. W. (2020). Corporate social responsibility and debt maturity: Australian evidence. Pacific Basin Finance Journal, 62, 101374. https://doi.org/10.1016/j.pacfin.2020.101374.

Olibe, K. O., Rezaee, Z., Flagg, J., and Ott, R. (2019). Corporate diversification, debt maturity structures and firm value: The role of geographic segment data. Quarterly Review of Economics and Finance, 74, 206-219. https://doi.org/10.1016/j.qref.2019.01.011.

Orman, C., and Köksal, B. (2017). Debt maturity across firm types: Evidence from a major developing economy. Emerging Markets Review, 30, 169-199. https://doi.org/10.1016/j.ememar.2016.12.001.

Pan, W. F., Wang, X., and Yang, S. (2019). Debt maturity, leverage, and political uncertainty. North American Journal of Economics and Finance, 50(April), 100981. https://doi.org/10.1016/j.najef.2019.04.024.

Rey, A., Tuccillo, D., and Roberto, F. (2020). Earnings management and debt maturity: Evidence from Italy. Corporate Ownership and Control, 17(3), 179-186. https://doi.org/10.22495/cocv17i3art14.

Salehi, M., and Sehat, M. (2019). Debt maturity structure, institutional ownership and accounting conservatism. Asian Journal of Accounting Research, 4(1), 35-51. https://doi.org/10.1108/ajar-05-2018-0001.

Surasmi, I. A., Luh, N., Wiagustini, P., Bagus, I., Purbawangsa, A., and Sedana, B. P. (2020). Determinant Of Firm Value: Debt Maturity As Moderator (Study In Manufacturing Industry In Indonesia). International Journal of Advance Science and Technology, 29(10), 6703-6716.

Surento, H., dan Fitriati, I. R. (2020). Kebijakan hutang perusahaan manufaktur di Indonesia. Al Tijarah, 6(3), 70-77.

Tesalonika, F. (2020). Kesiapan perusahaan untuk menerapkan pelaporan terintegrasi: penilaian laporan keberlanjutan perusahaan berdasarkan rerangka konseptual pelaporan terintegrasi. Widya Mandala Catholic University Surabaya.

VanKhanh, V. T., and Hung, D. N. (2020). Impact of earnings quality on the debt 
maturity: The case of Vietnam. Asian Economic and Financial Review, 10(1), 1-12. https://doi.org/10.18488/journal.aefr.2020.101.1.12.

Wang, H., and Zhang, J. (2017). Fair value accounting and corporate debt structure. Advances in Accounting, 37, 46-57. https://doi.org/10.1016/j.adiac.2017.02.002.

$\mathrm{Xu}, \mathrm{X}$., and Li, J. (2020). Asymmetric impacts of the policy and development of green credit on the debt financing cost and maturity of different types of enterprises in China. Journal of Cleaner Production, 264, 121574. https://doi.org/10.1016/j.jclepro.2020.121574. 